\title{
ステップ状の流量変化に対するチャネル乱流熱伝達の過渡応答
}

\section{Transient Response of Turbulent Heat Transfer to Step-Like Change of Flow Rate in Channel Flow}

$\begin{array}{rllll}\text { O正 山崎 } & \text { 龍朗 (関西大) } & \text { 正 } & \text { 小田 } & \text { 豊（関西大） } \\ \text { 正 松本 } & \text { 亮介 (関西大) } & \text { 正 } & \text { 香月 } & \text { 正司 (阪大名誉) }\end{array}$

Tatsuro Yamazaki ${ }^{1}$, Yutaka Oda ${ }^{1}$, Ryosuke Matsumoto ${ }^{1}$ and Masashi Katsuki ${ }^{2}$

${ }^{1}$ Kansai University, 3-3-35 Yamate-cho, Suita-shi, Osaka 564-8680, Japan

${ }^{2}$ Professor Emeritus of Osaka University

Key Words: Turbulent heat transfer, Unsteady flow, Pulsating flow, DNS

往復動内燃機関内の流れなどの非定常な乱流による運動量や熱の輸送現象を解明することは工学的に重要であり, 数值解析 (1), 実験(2)の両面から研究が進められている. 我々はこれまでに流量が周期的に増加・減少する脈動流を対象 に直接数值解析 (DNS) を実施し, 脈動流では運動量輸送と熱輸送の非相似性が生じ, 特に高周波数の場合 $\left(\omega^{+}=\right.$ 0.035) に顕著であることを明らかにした ${ }^{(3,4)}$. 本研究では, 脈動流における非相似性の発現機構を明らかにするために, 流量がステップ状に増加・減少する流れ場を対象とした DNS を実施し, 急激な流量変化に対する流れ場と温度場の応 答特性を調べた. 解析対象は平行平板間乱流であり, バルクレイノルズ数が $R e_{b}=8300 \sim 12000$ の範囲において流量を ステップ状に増加・減少させた. なお, $R e_{b}$ の範囲は既報の脈動流(3,4)における最小〜最大流量に設定し, 温度場の境界 条件には一様熱流束加熱条件を適用した. 図 1 に加速および減速する期間を $\Delta t^{+}\left(=\Delta t \cdot u_{\text {tz, mid }}^{2} / v\right)=89.8$ に設定した場 合 $\left(\omega^{+}=0.035\right.$ の脈動流と同程度の加速度 $)$ における $R e_{b}$ と壁面せん断応力 $\tau_{w}{ }^{+}$, およびヌセル下数 $N u$ の時間変化を示 す. なお, $u_{\varpi, \text { mid }}$ は $R e_{b} \approx 10150$ の定常流における摩擦速度である. 壁面せん断応力はレイノルズ数の時間変化に追従 して変化し, 加速の条件では加速後に, 減速の条件では減速後に一度減少(増加)し, その後定常状態に遷移していく 様子が見られる. 一方で, ヌセル下数の時間変化は加速の場合と減速の場合の両方において, レイノルズ数が変化した 後, ある一定の時間が経過してから変化し始める. そして, 変化の傾きもレイノルズ数やせん断応力と比較すると比較的 緩やかであることが分かる.これらの結果より, 脈動流の場合と同様に, ステップ状の流量変化に対しても壁面せん断応 カとヌセル卜数は異なる応答特性を示すことが分かった.

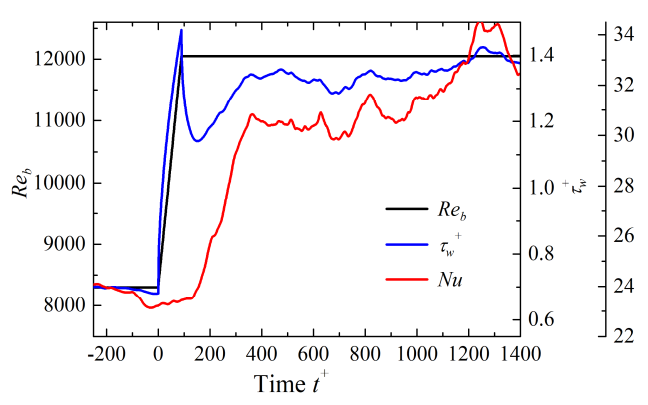

(a) Sudden acceleration

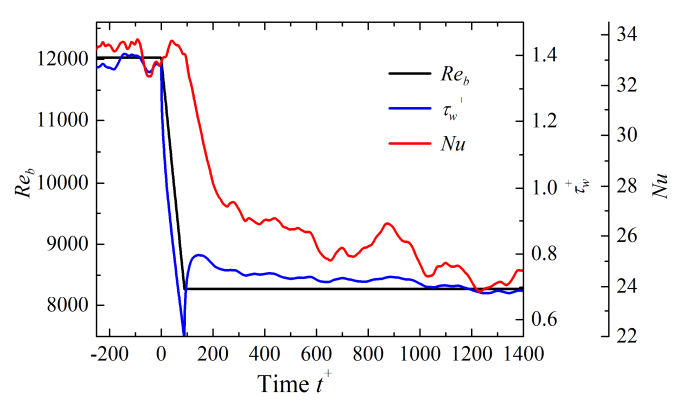

(b) Sudden deceleration

Fig. 1 Time variation of Reynolds number, wall shear stress, and Nusselt number.

\section{謝辞}

本研究の一部は, JSPS 科研費特別研究員奨励費 (No. 20J10618)の助成を受けて実施された. ここに記し謝意を表す.

\section{参考文献}

(1) Scotti, A. and Piomelli, U., Physics of Fluids, 13-5 (2001), 1367.

(2) Shiibara, N. et al., International Journal of Heat and Mass Transfer, 113 (2017), 490.

(3) 山崎・他 3 名, 日本機械学会論文集, 86-884 (2020), DOI:10.1299/transjsme.19-00197.

(4) Yamazaki, T. et al., Journal of Thermal Science and Technology, 15-2 (2020), DOI: 10.1299/jtst.2020jtst0017. 